\title{
THE RESPONSE OF HONEY BEES TO VARIATIONS IN SOLAR RADIATION AND TEMPERATURE
}

\author{
Robert M. BURRILL \\ The University of West Florida, Pensacola, Florida 32504 \\ Alfred DIETZ \\ University of Georgia, Athens, Georgia 30602
}

\begin{abstract}
SUMMARY
The development of the "Apicard " (Automatic honey-bee Counting and Recording Device) has contributed a means for continuous sampling of honey bee activity at the hive entrance and simultaneously recording the data obtained. These data provide a measure with which quantitative expressions of the daily activity cycle for a honey-bee colony can be made.

In this paper, activity responses to two weather elements, solar radiation and temperature are considered. While these two elements are naturally interrelated, the honey bees appear to respond to each differently. For temperature, the response is positive. Increasing temperatures result in increasing flight departures while decreasing temperatures show decreasing numbers of departures. In the case of solar radiation intensity, the response is both positive and negative. At low radiation levels, increasing intensity is associated with increasing numbers of flight departures but at solar radiation levels greater than 0.66 langleys, increasing intensities are associated with decreasing numbers of honey bee flight departures.
\end{abstract}

\section{INTRODUCTION}

The importance of the influence of meteorological elements on honey bee flight activity is well recognized. LUNDIE (1925) reported that flight frequencies are dependent not only on light intensity, humidity, temperature, and wind velocity, but also on atmospheric pressure. The flight behavior and uptake of sugar solution by individual honey bees in relation to meteorological phenomena were also studied by ScHUÁ (1952). In both studies, the success of the research depended upon developing some means for measuring variations in the flight activity of honey bees. However, the problem of measuring flight activity has been a critical one and to date a most difficult one to resolve satisfactorily. 
The first reported use of photoelectric cells for counting honey bees was made by BrittaIN (1933) using a standard colony. More recently, Kerfoot (1966) devised a photoelectric counter for the solitary bee (Agapostemon texanus), and SPANGLER (1969) designed one to be used with a small observation hive. Another design to count bees at the hive entrance has been reported by ERICKson et al. (1975). These efforts have proven that photoelectric cells can be used to count bees and thus provide a measure of honey bee activity. Photoelectric counting can be done automatically over long, continuous, periods of time requiring only minimal attention. However, means for discriminating between incoming and outgoing bees of a standard colony and for recording these counts are essential in the systems analysis of a honey bee colony.

To overcome these difficulties, we designed and constructed an automatic honey bee counting and recording device "Apicard" (Burrill and Dietz, 1973). This device continuously counts and records on magnetic tape for subsequent computer analysis the total number of individual honey bees leaving and returning to the hive every 30 seconds. Our development of the "Apicard " has been acknowledged as a breakthrough in solving the problem of separating and counting incoming and outgoing honey bees (VERBEeK and Verbeek, 1974). The rapid data acquisition that the "Apicard " provides produces a quantitative expression of the daily activity continuum as well as seasonal and annual variations in this continuum. Using flight activity and simutaneously occuring weather data, statistical techniques have been employed to demonstrate quantitatively how honey bees respond to temperature and solar radiation levels. The purpose of this paper is to show how honey bees respond to variations above the threshold level in these two parameters.

\section{MATERIAL AND METHODS}

The flight activity data used were collected by the "Apicard "from a normal colony of honey bees (Apis mellifera ligustica). Even though counts of departing honey bees were accumulated every 30 seconds by the system, the time period used in the analyses was 30 minutes because the available weather data were not similarly sensitive.

During each one-half hour period between 5:00 A.M. and 8:00 P.M., 30 periods in all, representative values for counts of departing honey bees, solar radiation intensity, temperature, relative humidity and atmospheric pressure were assembled. These data were collected for a 23 day sequence beginning April 22 and ending May 15. Data for May 5th are not included because they were incomplete.

All the data collected during this period were put on punch cards and the means as well as standard deviations for each parameter in each 30 minute time period computed. Values for each parameter were plotted against counts and linear regression analyses performed. Multiple correlations between counts and the several weather values were computed for each time interval.

\section{RESULTS AND DISCUSSION}

The computed means and standard deviations for all parameters are presented in Table 1. These data provide the basis for studying the interrelationship between 


\begin{tabular}{|c|c|}
\hline as $\mp$ & 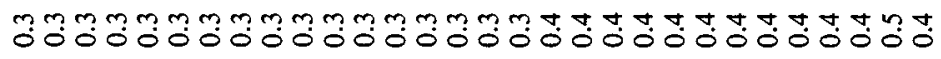 \\
\hline $\begin{array}{r}(\mathbf{( 3 y / 8 )}) \\
\cdot \operatorname{unn} H \cdot \operatorname{sad} S\end{array}$ & 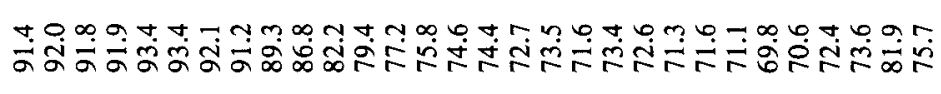 \\
\hline ds $\mp$ & 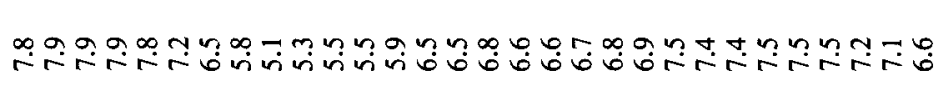 \\
\hline 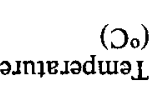 & 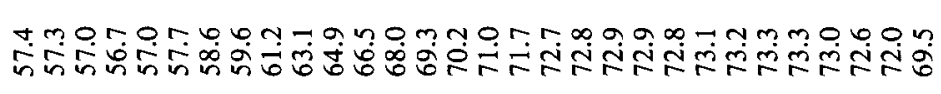 \\
\hline đs $\mp$ & 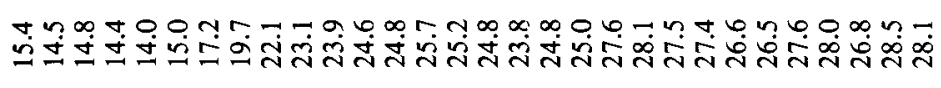 \\
\hline 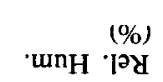 & 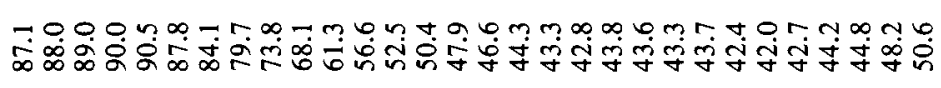 \\
\hline as $\mp$ & 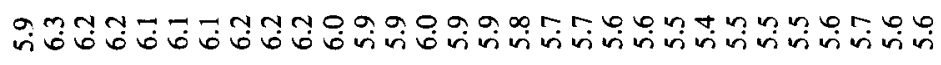 \\
\hline $\begin{array}{l}\text { (sJeq!II!U) } \\
\text { asnssəدd }\end{array}$ & 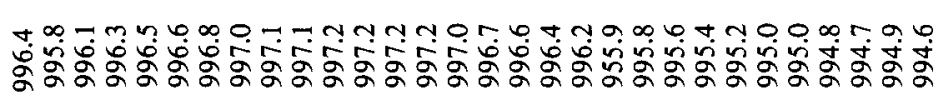 \\
\hline as $\mp$ & 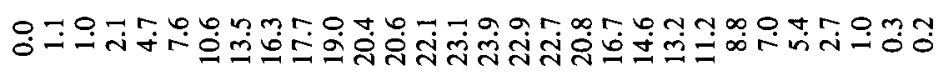 \\
\hline 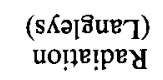 & 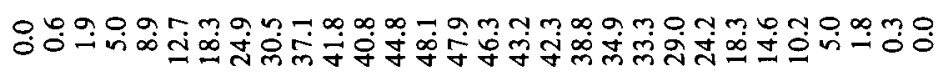 \\
\hline as $\mp$ & 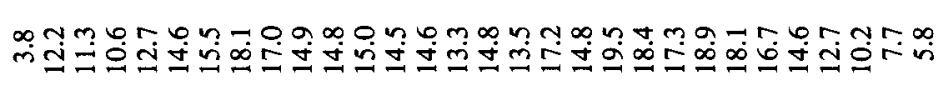 \\
\hline $\begin{array}{l}\text { səaq Kəuoy } \\
\text { su!juedəp } \\
\text { jo junoว }\end{array}$ & 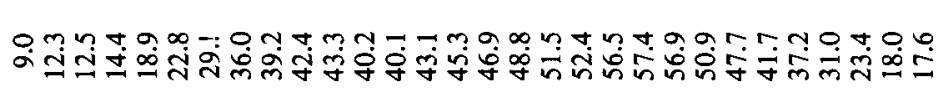 \\
\hline $\begin{aligned}\left(\operatorname{sinoH}_{1}\right) \\
\text { poị. }\end{aligned}$ & 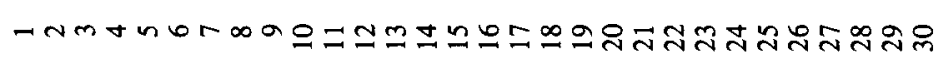 \\
\hline
\end{tabular}


dependent honey bee flight activity data and the independent weather parameters. The mean values of these data illustrate the normal cycle in all parameters and the standard deviations demonstrate the degree of variability that occured within these cycles.

In order to identify the more important independent parameters, honey bee flight departure counts were plotted against each weather factor. The result of this analysis was that temperature and radiation appeared to be the major factors of weather influencing honey bee flight initiation. Efforts to determine how honey bees responded to variations in each as well as both factors operating together showed that the correlation values of two of the weather parameters, solar radiation intensity and temperature were the most important ones in terms of explaining count variations. For each of the time periods either temperature (12) or radiation (12), a total of 24 out of the 30 time periods had the highest correlation values (Table 2). Visual inspection of data previously collected confirmed the fact that honey

TABL. 2. - Correlation values between observed mean honey bee departure counts and weather factors.

\begin{tabular}{c|c|c|c|c}
\hline \hline Period & Radiation & Pressure & Humidity & Temperature \\
\hline 1 & 0.00 & 0.14 & 0.49 & $0.71^{*}$ \\
2 & 0.74 & 0.18 & 0.34 & 0.45 \\
3 & 0.37 & -0.06 & 0.29 & $0.63^{*}$ \\
4 & -0.14 & 0.12 & 0.34 & $0.62^{*}$ \\
5 & 0.07 & 0.19 & 0.30 & $0.58^{*}$ \\
6 & 0.35 & 0.34 & 0.35 & $0.42^{*}$ \\
7 & $0.66^{*}$ & 0.44 & 0.21 & $0.19^{*}$ \\
8 & $0.76^{*}$ & 0.54 & 0.00 & 0.17 \\
9 & $0.80^{*}$ & 0.62 & -0.39 & 0.04 \\
10 & $0.87^{*}$ & 0.34 & -0.48 & 0.17 \\
11 & $0.78^{*}$ & 0.42 & -0.55 & 0.32 \\
12 & $0.75^{*}$ & 0.59 & -0.59 & 0.45 \\
13 & 0.56 & 0.50 & -0.62 & 0.41 \\
14 & 0.43 & 0.41 & -0.55 & 0.33 \\
15 & 0.53 & 0.30 & -0.58 & 0.34 \\
$-16-$ & $0.53^{*}$ & 0.10 & -0.50 & 0.24 \\
17 & $0.54^{*}$ & 0.16 & -0.54 & 0.23 \\
18 & $0.55^{*}$ & 0.26 & -0.47 & 0.27 \\
19 & 0.53 & 0.30 & -0.65 & 0.43 \\
20 & 0.24 & 0.24 & -0.44 & 0.43 \\
21 & 0.35 & 0.33 & -0.33 & $0.48^{*}$ \\
22 & 0.41 & 0.54 & -0.39 & 0.54 \\
23 & 0.44 & 0.51 & -0.51 & $0.57^{*}$ \\
24 & 0.35 & 0.47 & -0.46 & $0.61^{*}$ \\
25 & 0.21 & 0.44 & -0.36 & $0.61^{*}$ \\
26 & 0.41 & 0.41 & -0.21 & $0.53^{*}$ \\
27 & $0.51^{*}$ & 0.29 & 0.11 & 0.38 \\
28 & $0.40^{*}$ & 0.31 & 0.10 & 0.39 \\
29 & 0.03 & 0.26 & 0.04 & $0.33^{*}$ \\
30 & 0.23 & 0.35 & -0.10 & $0.64^{*}$ \\
\hline
\end{tabular}

* Highest correlation value for time period. 
bees would not fly if temperatures did not exceed $9^{\circ} \mathrm{C}$ regardless of light intensity. This is in basic agreement with previous findings by others seeking to establish a positive link between honey bee activity and weather. Also, honey bees will not fly if there is no light regardless of temperature. The relationships between count values and radiation, is illustrated in Fig. 1. It is apparent that radiation has both a positive and negative effect with the break point occuring at the radiation value of 0.66 Langleys. In both morning and afternoon the radiation seems positively related to flight departures while during the high sun period, radiation seems negatively related to flight departures. This confirms observations by W. G. WeLLington (1957) who showed that insect activity seems to decrease during the solar noon period. GARY (1967) noted that there seemed to be a U-shaped pattern in daily flights from mid-morning to mid-afternoon. Similar reports have been presented by LuNDIE (1925) and FRISCH (1965).

Since the mean number of departing bees is greater in the afternoon and since temperatures are also higher at the same time of day, efforts were made to see if the discrepancy between mean bee departures in the morning and afternoon was somehow related to temperature differences. Comparisons of residuals from regression analyses for both morning and afternoon periods with temperature values failed to demonstrate

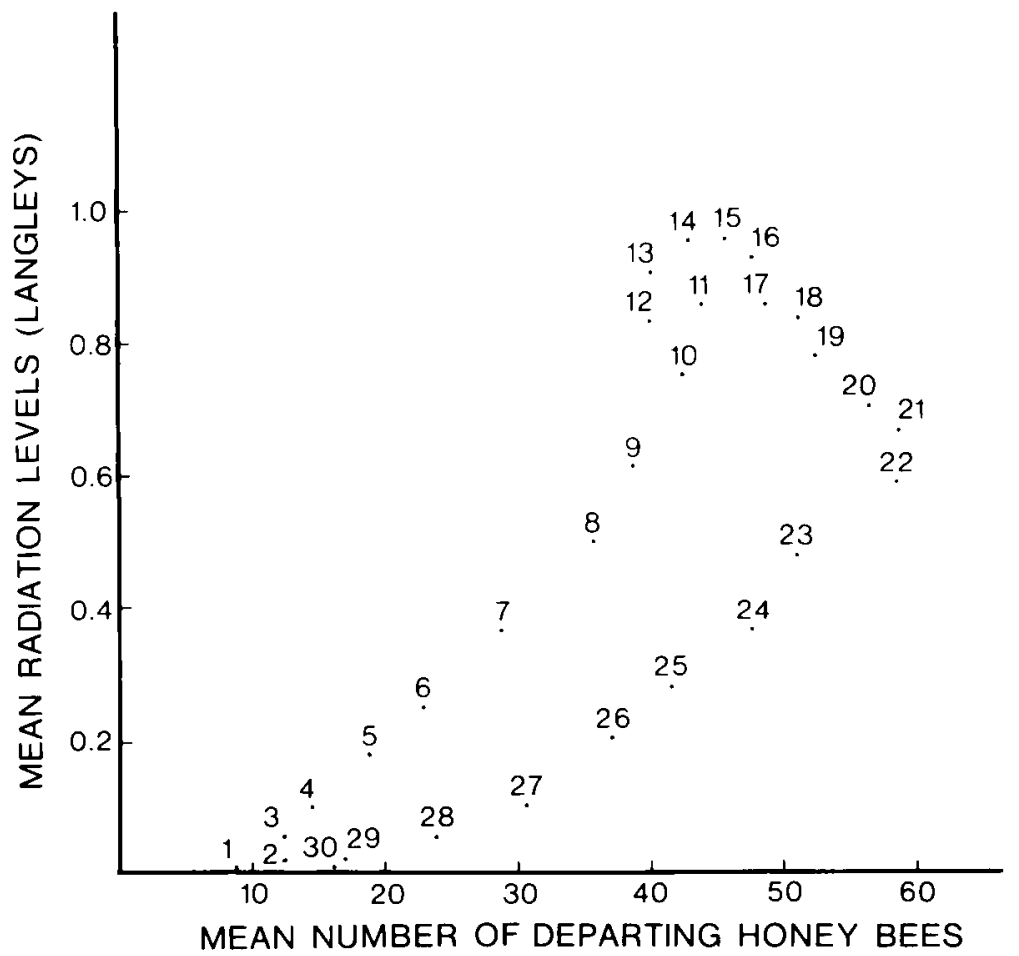

FIG. 1. - Mean number of honey bees departing at designated time periods, 1 through 30 , and different mean radiation levels. 
any temperature relationship. Apparently the temperature influences were inherent in the radiation values and thus regression analyses of radiation did not provide a method of separation.

Fig. 2 which illustrates the temperature and count relationship is of interest because it shows that the same break points did reappear most significantly in the afternoon. From time period 1 through 9, mean bee departure counts increased considerably while temperature did not. Equally, from period 21 through 29 counts decreased although temperatures remained fairly constant. Across solar noon or periods 10 through 20 , a much more dramatic change in mean counts occured with temperature changes. Here too, analyses of residuals from regressions based on temperature did not provide the separation between temperature effects and radiation effects. Nevertheless, a tantalizing relationship between mean departure counts and radiation as well as temperature seemed to exist.

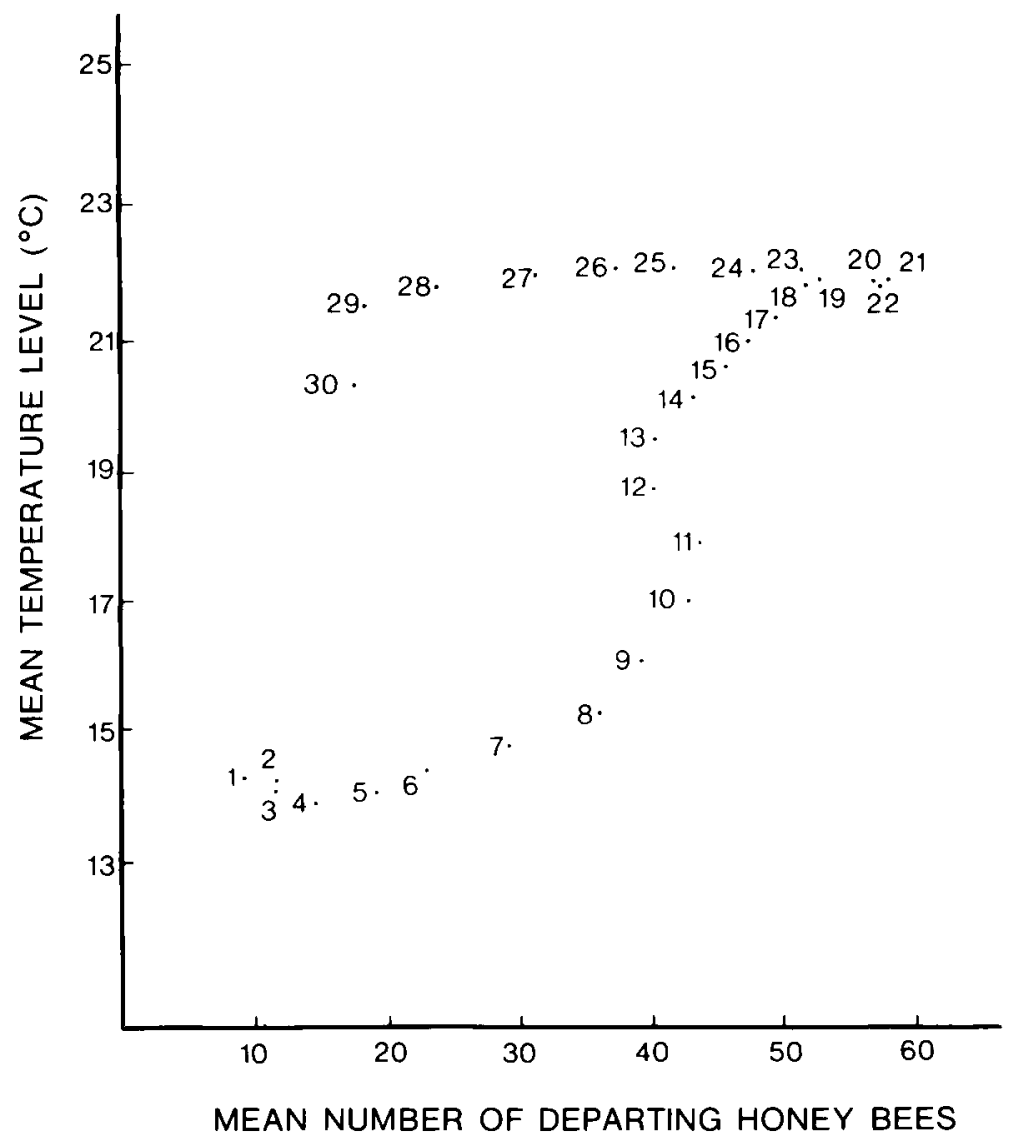

Fig. 2. - Mean number of honey bees departing at designated time periods and different mean temperatures. 
If temperature values are compared with mean count values for those periods in which radiation values are similar, an interesting fact is brought to light. In the morning before the sun came up, the temperature value was $4.9^{\circ} \mathrm{C}$ above the base value of $9.0^{\circ} \mathrm{C}$ and the mean count value was 9.0. In the evening after the sun had set the temperature value was $11.7^{\circ} \mathrm{C}$ above the base and the mean count value was 17.6. At time periods 6 and 27 when the radiation values were both 0.1 Langleys, the difference in temperatures was $8.5^{\circ} \mathrm{C}$ and the difference in mean bee departure counts was 12.1. This suggested that an approximate $1.5: 1$ ratio existed between temperatures and mean counts. Therefore, mean count values can be determined by computing the difference between temperature values for each time period and the base temperature of $9.0^{\circ} \mathrm{C}$. The residuals when plotted against radiation values show an interesting development (Fig. 3). The differences existing between the mean bee departure count for morning and afternoon under similar radiation values had virtually disappeared.

Regression analyses were applied by the least square method to mean departure counts residuals and radiation values (Fig. 3). Counts based upon radiation were then

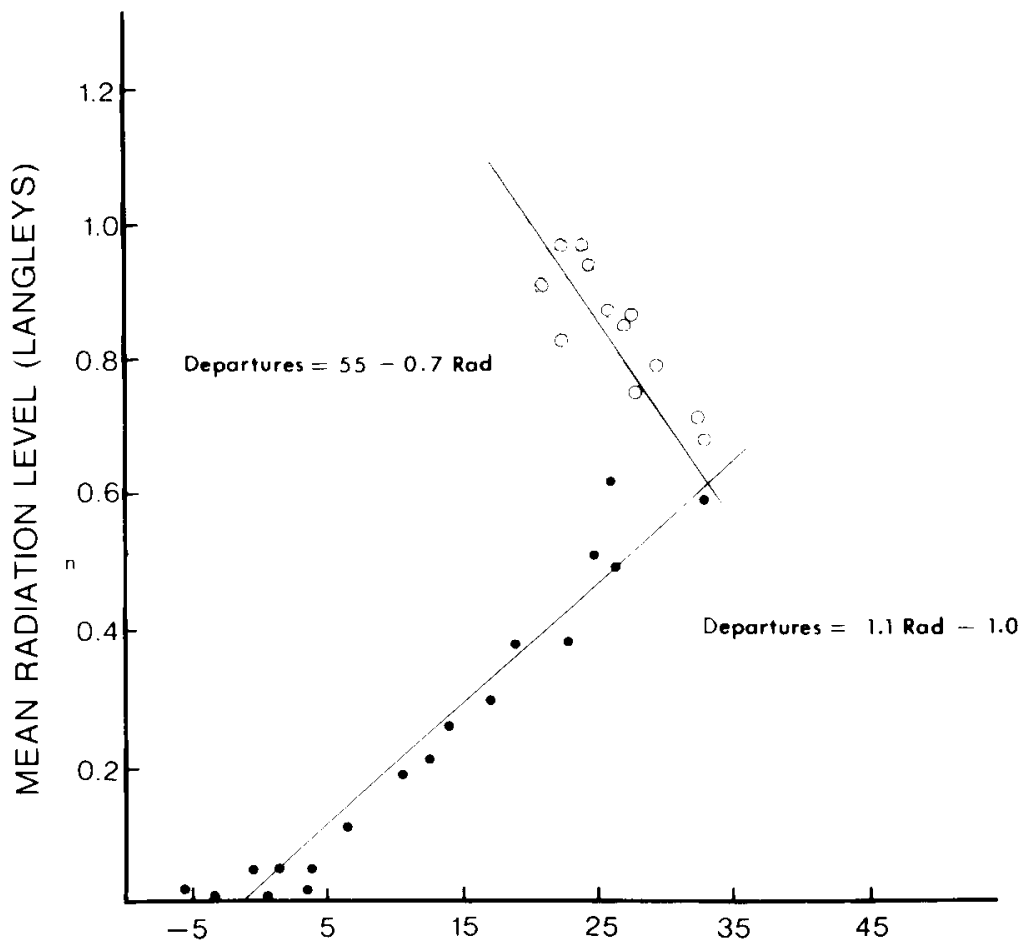

MEAN HONEY BEE DEPARTURE RESIDUALS

$$
(x-x \text { temp) }
$$

FIG. 3. - Mean honey bee departure residuals $(\mathrm{x}-\mathrm{x}$ temp.) at different mean radiation levels (i.e., at $14.4^{\circ} \mathrm{C}$ and 27 mean departures, 10 departures will be due to temperature and 27 minus 10 or 17 will be due to radiation intensity). 
determined. These added to the count values based upon temperature and the sums for each period were plotted against the mean count values observed (Fig. 4).

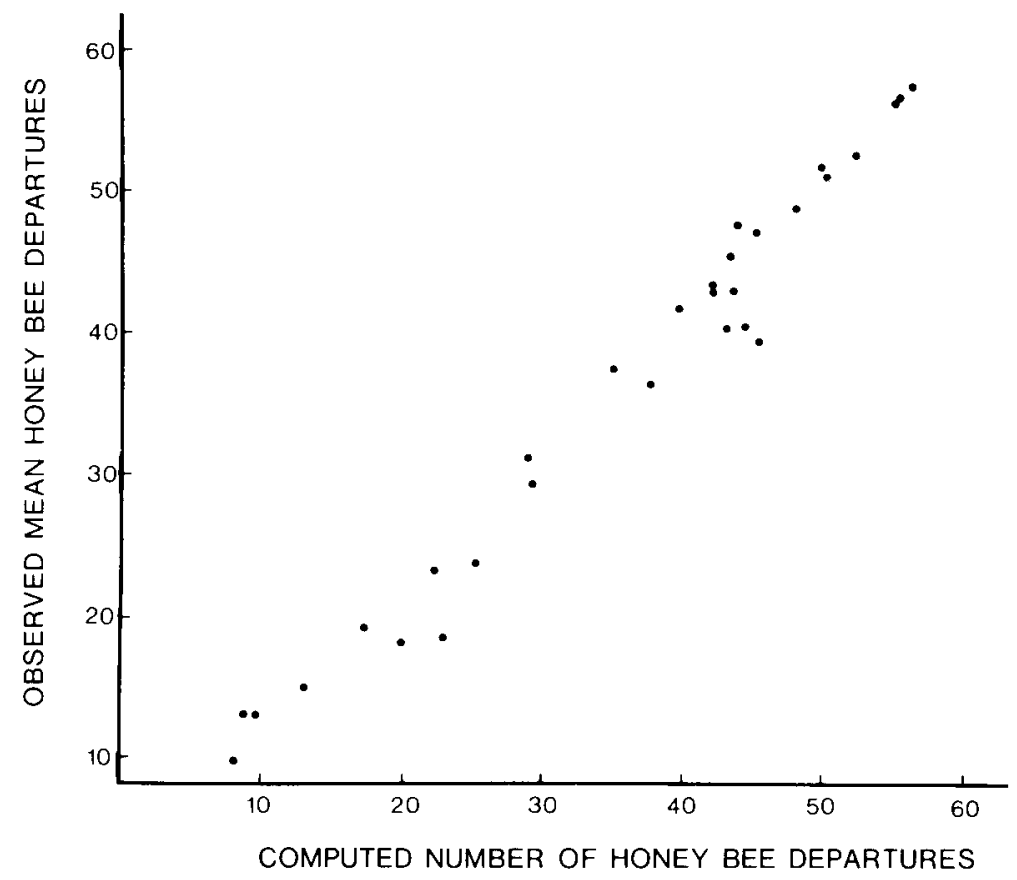

FIG. 4. - Observed versus computed honey bee flight departures based upon temperatures and solar radiation intensities.

These analyses have enabled us to identify influences on flight activity of weather parameters which are interrelated. Above threshold levels one factor, temperature is only predictive when the other factor, radiation intensity, is considered and viceversa. Under the circumstances, activity responses to temperature appear to be approximately linear. Activity responses to solar radiation intensity appear to be both positive and negative with the break point occuring at approximately 0.66 Langleys.

Over the past few years, considerable attention has been given to the Africanized honey bee which has been spreading over the South American continent. Concern has been expressed that these honey bees will invade the United States. However, some authorities feel that these tropical honey bees will not be able to survive the middle latitude winters and therefore are no real threat. Our findings suggest an alternative. The African bee evolved in tropical Africa, while the honey bees used in this country are of European origin. It is quite possible that the African honey bee responds to solar radiation intensity differently than does the European honey bee. If the African bee tolerates higher solar radiation intensity values it would naturally be 
capable of greater productivity in the tropics than the European bee because it would have greater periods of activity. As a point of interest, the African honey bee's greater productivity was the reason this bee was brought into Brazil in the first place. On the other hand, the European honey bee, being in its own environment in the middle latitudes should be better able to hold its own here in this country even if an invasion by the African bee should occur, since it is less dependent on tropical solar radiation intensity as well as more tolerant of low temperatures. Evidence to support this contention can be drawn from the way the African bee has spread over South America. The rates of advance have been much greater in the tropical areas than in the middle latitude areas of that continent. Consequently, a detailed study of the response of African honey bee to solar radiation intensity might well confirm our postulation.

Received for publication in May 1981.

\section{RÉSUMÉ \\ REACTION DES ABEILLES AUX VARIATIONS DE LA RADIATION SOLAIRE ET DE LA TEMPERATURE}

La mise au point de l'" Apicard " (Système automatique de comptage et d'enregistrement des abeilles) a fourni le moyen d'échantillonner en continu l'activité des abeilles à l'entrée de la ruche et d'enregistrer simultanément les données obtenues. Celles-ci servent de base pour exprimer quantitativement le cycle journalier d'activité d'une colonie d'abeilles.

Dans cet article, on considère les réactions de l'activité à 2 facteurs météorologiques, la radiation solaire et la température. Tandis que ces deux facteurs sont dans la nature étroitement liés, les abeilles semblent réagir différemment à chacun d'eux. En ce qui concerne la température, la réaction est positive. Lorsque la température croit, les envols augmentent, tandis qu'ils diminuent lorsqu'elle décroit. Dans le cas de la radiation solaire, la réaction est à la fois positive et négative. Aux faibles radiations les envols augmentent avec l'intensité, mais lorsque celle-ci dépasse 0,66 Langleys un accroissement de l'intensité entraine une diminution du nombre d'envols.

\section{ZUSAMMENFASSUNG}

DIE REAKTION VON HONIGBIENEN AUF VARIATIONEN IN DER SONNENEINSTRAHLUNG UND DER TEMPERATUR

Die Entwicklung des "Apicard " (Automatische Zähl- und Registriereinrichtung für Bienen) hat das Instrument geliefert, um die Aktivitäten der Bienen am Flugloch kontinuierlich zu beobachten und die erzielten Daten gleichzeitig zu registrieren. Diese Daten liefern die Grundlage für eine quantitative Darstellung des täglichen Aktivitätszyklus des Bienenvolkes.

In dieser Arbeit werden die Aktivitätsreaktionen auf zwei Elemente der Witterung, die Sonneneinstrahlungen und die Temperatur, untersucht. Während diese beiden Elemente in der Natur voneinander abhängen, scheinen die Bienen auf jede von ihnen verschieden zu reagieren. Gegenüber der Temperatur ist die Reaktion positiv. Steigende Temperaturen führen zu einer steigenden Anzahl von Abflügen, während fallende Temperaturen eine fallende Anzahl von Ausflügen zeigen. Im Falle der Intensität der Sonneneinstrahlung, kann die Reaktion sowohl positiv wie negativ sein. Bei niedrigem Strahlungsniveau ist eine Steigende Intensität mit einer steigenden Anzahl der Abflüge verbunden, aber bei Sonneneinstrahlungen von über 0,66 Langleys sind steigende Intensitäten mit einer fallenden Zahl der Ausflüge der Bienen verbunden. 


\section{LITERATURE CITED}

BritTaIN W. H., 1933. - Apple pollination studies in the Annapolis Valley, N. S., Canada 19281932. Can. Dept. Agr. Bull., 162, 119-125.

BURRILl R. M. and DIETZ A., 1973. - An automatic honey-bee counting and recording device (Apicard) for possible systems analysis of a standard colony. Amer. Bee Jour., 113, 216-218.

BURrill R. M., DieTz A. and . Kossack C.F., 1977. - Flight activity analysis of honey-bees using Apicard generated data. Apiacta, 12, 110-112, 116.

Erickson E. H., Miller H. H. and Sikkema D. J., 1975. - A Method of Separating and Monitoring Honey-bee Flight Activity at the Hive Entrance. Jour. Apicult. Res., 14, 119-125.

FABerge A. C., 1943. - Apparatus for recording the number of bees leaving and entering a hive. J. Sci. Instr., 20, 28-31.

Frisch K. von, 1965. - Tanzsprache und Orientierung der Bienen. Berlin-Heidelberg, Springer Verlag.

GARY N.E., 1967. - Diurnal variations in the intensity of flight activity from honey bee colonies. J. Apic. Res., 6, 65-68.

KERFOOT W. B., 1966. - A photoelectric activity recorder for studies of insect behavior. Jour. of Kan. Ent. Soc., 39, 629-633.

LUNDIE A. E., 1925. - The flight activities of the honey bees. Bull. USDA No. 1328.

SCHUÁ L., 1952. - Untersuchungen über den Einfluss meteorologicher Elemente auf das Verhalten der Honigbienen (Apis mellifica). Z. vergl. Physiol., 34, 258-277.

SpaNGler H. G., 1969. - Photoelectrical counting of outgoing and incoming honey-bees. J. Econ. Ent., 62, 1183-1184.

VERBEek B. and VerbeEk R., 1974. - Eine Methode zur Registrierung des Aus- und Einfliegene einzelnes Bienen. Apidologie, 5, 289-293.

Wellington W. G., 1957. - The synoptic approach to studies of insects and climate. Annu. Rev. of Entomol., 2, 143-162. 